\title{
Immunoglobulin Heavy Chain Joining Region
}

National Cancer Institute

\section{Source}

National Cancer Institute. Immunoglobulin Heavy Chain Joining Region. NCI Thesaurus.

Code C118496.

The portion of the heavy chains of immunog lobulin molecules where the variable and constant regions meet. 